\title{
Ascochyta Blight Impact, Cold and Drought Stresses on Cicer arietinum L. Genotypes of Iran
}

\author{
Alireza Taleei* \\ Department of Agronomy \& Plant Breeding, University of Tehran, Iran
}

Submission: July 13, 2017; Published: July 31, 2017

*Corresponding author: Alireza Taleei, Department of Agronomy \& Plant Breeding, University of Tehran, Iran, Email: ataleei@ut.ac.ir

\section{Abiotic Stresses}

Plants form an integral part of human life. They have been usedChickpea (Cicer arietinum L.) the world's second most important food legume, is globally cultivated on area of 13.20 million hectare with an annual production of 11.62 million tons. The global demand for chickpea in 2020 is projected to be 17.0 million tons [1]. In the Mediterranean area, sowing earlier or as autumn or spring cropping provides chickpea with a more durable growth season, efficient use of soil moisture and higher yield [2]. However, a lack of cold tolerant varieties causes yield losses in different chickpea areas. Many plants increase cold tolerance due to cold acclimation process that allows them to develop essential tolerance for cold stress survival through multiple levels of biochemical and cell biological changes. Cold stress affect many plant physiological and biochemical components and induces cascades of alterations in metabolic pathways, amongst them the membrane fatty acid compositions, the activity of antioxidative enzymes and the regulation of gene expression. Numerous investigations of different aspects of cold acclimation and in particular the recently developed methods of metabolomics profiling have detected changes in nearly all aspects of plant metabolism [3]. Temperature reduction affects membrane-linked processes due to its fluidity and permeability [4]. To assess changes in membrane solute and electrolyte leakage, malondialdehyde (MDA) content as the final product of lipid per-oxidation, lipoxygenases activity (LOX) as a responsible factor of membrane degradation and unsaturated fatty acid (UFAs) ratio compared to saturated (SFAs) ones as fluidity and stability preserving factor can demonstrate a reliable path to realize these processes.Further, membrane damage leads to the production of reactive oxygen species (ROS), which cause oxidative stress [5]. ROS affect many cellular functions by damaging carbohydrates, nucleic acids, oxidizing proteins, and causing lipid peroxidation [6]. However, cells are equipped with excellent defense mechanisms to detoxify the harmful effects of ROS [7]. Therefore studying the activity these antioxidants, including superoxide dismutase (SOD), catalase
(CAT) and guaiacol peroxidase (GPX) may help us to recognize this mechanism accurately. During stresses proline acts as cryoprotection, carbon and nitrogen storage, $\mathrm{pH}$ stabilizer, cell redox balancer and stress-related growth-regulating signal, so that plants with elevated proline levels have been reported to exhibit enhanced tolerance to abiotic stresses [8]. Changes in proline content can therefore be considered as an important factor in plant adaptation to abiotic stresses such as cold. The acclimation process also involves expression of diverse stressresponsive genes to maintain metabolic homeostasis during stress or to be able to re-establish subsequent to the stress period [5]. It thus seems necessary to examine the program at molecular, and particularly transcriptional level, surveying SOD, CAT, and LOX gene experiments. Furthermore, assessing rubisco and tubulin gene expression can be helpful in understanding the nature of the induced cold stress effect on plants. It is now well established that in vivo rubisco activity is rapidly regulated to control the flux through the photosynthetic carbon reduction cycle in response to fluctuations in the environment [9]. On the other hand, microtubules are key elements of the cytoskeleton and have recently come to appreciate for their role in signaling and regulation. They critical conduits for cellular trafficking and can serve as a template for the interaction of signaling proteins [10]. According to our studies cold acclimation has a positive effect on chickpea plants during long-term cold stress [11]. The productivity of food legumes such as chickpea are limited by multiple stresses like drought, however, the severity of these stresses in the field conditions is changeable. According to some experiments which were carried out for screening some of the drought tolerant Kabuli and Desi chickpea genotypes and characterization drought tolerance indices of some lines (28 of each them along with two check varieties of Kabuli and Desi chickpeas) in the Experimental site of the Department of Agronomy, University of Tehran, Karaj, Iran during February and August 2014. Two genotypes of Kabuli genotypes namely 101, 302, and Jam (check cultivar) were identified as tolerant 
and 333 and 314 were susceptible genotypes in this study, whereas genotypes 21, 25, and 166 detected as moer tolerant in the average of drought stress and non-stress conditions. The susceptible genotypes also were 314 and 333 that can were useful bases as extreme selected lines for mechanisms studies in development breeding programs to drought tolerance in chickpea $[12,13]$.

\section{Biotic Stresses}

Ascochyta blightis the major constraint and the most destructive disease for chickpea production in Central and West Asia and North Africa (CWANA) region. The response of chickpea genotypes against this disease, we carried out a research in the International Center for Agricultural Research in Dry Areas (ICARDA) in 2007. Effects of four pathotypes of A. rabiei in three spore concentrations were investigated on disease score (DS) and leaf infection percentage (LI) of two genotypes of chickpea namely Bivanij (Iranian Local variety) and ICCI2004 using systematic and mini-dome methods. The layout of this study was factorial experiment based on completely randomized design with three replications. Results revealed significant differences between genotypes, isolates and concentrations for DS and LI. New variant of phenotype IV developed highest pathogenicity on both genotypes. Lower coefficient of variation in the second method confirmed higher precision of mini-dome trial. There was significant correlation between LI and DS. Disease score for Bivanij (susceptible to Ascochyta blight) were 3.5 and 4.0 under $2 \times 103$ spores per ml concentration which suggested presence of some minor Ascochyta blight resistance genes in this genotype. Effect of spore concentration was divided into linear and quadratic components. Disease severity increased significantly due to the spore concentration increase and its trends which was linear. Both genotypes were susceptible to pathotype IV, whereas only ICCI2004 was resistant to other pathotypes. The highest spore concentration (2x105 spores per ml) developed the most discrimination between two chickpea genotypes [1416].

Due to above mentioned paragraphs, I could conclude that abiotic and biotic stresses could have sever yield losses which needs to have serious consideration about capability of plant land races.

\section{References}

1. Varshney RK, Thudi M, Nayak PN, Gaur PM, Kashiwagi J, et al. (2014) Genetic dissection of drought tolerance in chickpea (Cicer arietinum L.). Theor Appl Genet 127(2): 445-462.
2. Clarke HJ, Siddique KHM (2004) Response of chickpea genotypes to low temperature stress during reproductive development. Field Crops Res 90: 323-34.

3. Cook D, Fowler S, Fiehn O, Thomashow MF (2004) A prominent role for the CBF cold response pathway in configuring the low-temperature metabolome of Arabidopsis. Proc Natl Acad Sci USA 101(42): 1524315248.

4. Los DA, Miranov KS, Allakhverdiew SI (2013) Regularity role of membrane fluidity in gene expression and physiological functions. Photosynth Res 116(2-3): 489-509.

5. Senthil-Kumar M, Kumar G, Srikanthbabu V, Udayakumar M (2007) Assessment of variability in acquiredin thermo tolerance: potential option to study genotypic response and relevance of stress genes. J Plant Physiol 164: 111-123.

6. Foyer CH, Noctor G (2005) Redox homeostasis and antioxidant signaling: a metabolic interface between stress perception and physiological responses. Plant Cell 17(7): 18866-18875.

7. Gill SS, Tuteja N (2010) Reactive oxygen species and antioxidant machinery in abiotic stress tolerance in crop plants. Plant Physiol Biochem 48(12): 909-930.

8. Maggio A, Miyazaki S, Veronese P, Fujita T,Ibeas Jl, et al. Does proline accumulation play an active role in stress-induced growth reduction. Plant J 32(6): 699-712.

9. Galmes J, Aranjuelo I, Medrano H, Flexas J (2013) Variation in Rubisco content and activity under variable climatic factors. Photosynth Res 117(1-3): 73-90.

10. Farajalla MR, Gulick PJ (2007) The a-tubulin gene family in wheat and differential gene expression duringcold acclimation. Genome 50(5): 502-510.

11. Kazemi-Shahandashti SS, Maali-Amiri R, Zeinali H, Khazaei M Taleei A, et al. (2014) Effect of short-term cold stress on oxidative damage and transcript accumulation of defense-related genes in chickpea seedling. Journal of Plant Physio 171(13): 1106-1116.

12. Taleei A, Shaabani J (2016a) Yield Potential Analysis of Kabuli Chickpea Genotypes in water stress Conditions. Advanced Science and Technology Letters 142: 1-8.

13. Taleei A, Shaabani J (2016b) Yield Potential Analysis of Desi Chickpea Genotypes in water stress Conditions. Advanced Science and Technology Letters 142: 9-16.

14. Kanouni H, Talei A, Peyghambari SA, Okhovat SM, Abang M (2010) Impact of pathotype and spore concentrations on Ascochyta blight incidence in two chickpea (Cicer arietinum L.) genotypes. Iranian Journal of Crop Sci 13(2): 368-379.

15. Kaplan F, Kopka J, Haskell DW, Zhao W, Schiller C, et al. (2004) Exploring the temperature-stress metabolome of Arabidopsis. J Plant Physiol 136(4): 4159-4168.

16. Rai AN, Penna S (2013) Molecular evolution of plant P5C5 gene involved in proline biosynthesis. Mol Biol Rep 40(11): 6429-6435. 


\section{Your next submission with Juniper Publishers will reach you the below assets}

- Quality Editorial service

- Swift Peer Review

- Reprints availability

- E-prints Service

- Manuscript Podcast for convenient understanding

- Global attainment for your research

- Manuscript accessibility in different formats

( Pdf, E-pub, Full Text, Audio)

- Unceasing customer service

Track the below URL for one-step submission https://juniperpublishers.com/online-submission.php 